UNIVERSITAS MUHAMMADIYAH MALANG JP2SD (JURNAL PEMIKIRAN

DAN PENGEMBANGAN SEKOLAH DASAR)

http://ejournal.umm.ac.id/index.php/jp2sd

p-ISSN: 2338-1140 e-ISSN: 2527-3043

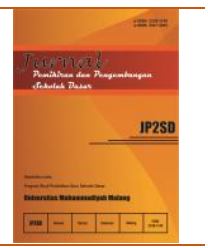

\title{
Visualisasi dan Makna Filosofi Motif Batik Teratai di Galeri Soendari Berbasis Penguatan Pendidikan Karakter
}

\author{
Arinta Rezty Wijayaningputri ${ }^{\text {a1 }}$, Belinda Dewi Regina ${ }^{\text {a2 }}$ \\ ${ }^{a}$ Pendidikan Guru Sekolah Dasar, Universitas Muhammadiyah Malang, Indonesia \\ 19arinta@umm.ac.id, ${ }^{2}$ belindadewi@umm.ac.id
}

\begin{tabular}{ll}
\hline INFORMASI ARTIKEL \\
\hline Riwayat: \\
Diterima & 27 Juli 2020 \\
Revisi & 30 Agustus \\
& 2020 \\
Dipublikasikan & 21 September \\
& 2020
\end{tabular}

Kata kunci:

Visualisasi, makna filosofi, Batik Teratai, Penguatan

Pendidikan Karakter

\begin{abstract}
ABSTRAK
Penelitian ini bertujuan untuk (1) Mendeskripsikan Visualisasi Motif Batik Teratai di Galeri Soendari Berbasis Penguatan Pendidikan Karakter, (2) Mendeskripsikan Makna Filosofi Motif Batik Teratai di Galeri Soendari Berbasis Penguatan Pendidikan Karakter, (3) Menganalisis muatan karakter pada Motif Batik Teratai. Penelitian ini menggunakan pendekatan kualitatif dengan jenis penelitian deskriptif. Subjek dalam penelitian ini yaitu motif batik Malangan. Hasil penelitian yang diperoleh adalah (1) Di dalam Motif Batik Teratai terdapat beberapa visual atau bentuk motif diantaranya motif bunga teratai, sulur-sulur dan daun dari bunga teratai. (2) Beberapa motif dari Batik Teratai memeiliki makna filosofi yaitu untuk motif bunga teratai selain melambangkan keindahan juga memiliki makna kesuburan dimana diharapkan pemakainya senantiasa subur makmur dan terpelihara jiwa dan raganya, sedangkan untuk sulur-sulur merupakan simbol bahwa perwujudan suatu kehidupan itu akan terus berlangsung, tumbuh dan berkembang tapi tak abadi dan senantiasa mengingatkan bahwa manusia pasti akan mati dan makna filosofi daun dari bunga teratai adalah mengajarkan tentang kehidupan kaya yang harus disyukuri dan dijaga. (3) Muatan nilai karakter yang bisa diambil dari Motif Bunga Teratai dapat dilihat dan dianalisis antara lain dari (bentuk/visual) maupun warna yang ada dalam batik teratai.
\end{abstract}

\section{ABSTRACT}

Keywords:
Visualization, philosophical meaning, Lotus Batik, Strengthening Character Education

The purpose of this research is to (1) describe the visualization of the lotus batik motif in the Soendari Gallery based on the strengthening of character education, (2) to describe the meaning of the philosophy of the lotus batik motif in the Soendari Gallery based on strengthening character education, (3) analyze the character content of the lotus batik motif. This research uses a qualitative approach with descriptive research type. The subject of this research is the Malangan batik motif. The results obtained are (1) In 


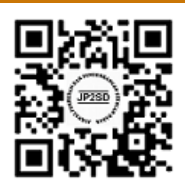

Copyright (C 2020, Arinta Rezty Wijayaningputri, Belinda Dewi Regina

This is an open access article under the CC-BY-SA license the Lotus Batik Motif, there are several visuals or forms of motifs including lotus motifs, tendrils and leaves from lotus flowers. (2) Some of the motifs of Batik Teratai have a philosophical meaning, namely for the lotus flower motif in addition to symbolizing beauty it also has the meaning of fertility where it is expected that the wearer will always be fertile, prosperous and nourished in body and soul, while for tendrils it is a symbol that the manifestation of a life will continue. It grows and develops but is not eternal and always reminds us that humans will definitely die and the philosophical meaning of the leaves of the lotus flower is to teach about a rich life that must be grateful for and guarded. (3) The contents of the character values that can be taken from the Lotus Flower Motif can be seen and analyzed, among others, from the (form/visual) and colors in the lotus batik.

How to cite: Arinta Rezty Wijayaningputri, Belinda Dewi Regina. (2020). Visualisasi dan Makna Filosofi Motif Batik Teratai di Galeri Soendari Berbasis Penguatan Pendidikan Karakter. Jurnal Pemikiran dan Pengembangan Sekolah Dasar, Vol 8 No 2, 148-156. doi:10.22219/jp2sd.v8i2.13813

\section{PENDAHULUAN}

Hasil kreativitas seni yang sangat bernilai dan terkenal sudah menjai warisan yang diberi oleh Nenek moyang kita sebagai bangsa Indonesia, di antaranya batik. Batik adalah salah satu seni budaya Indonesia yang menyatu dengan masyarakat sejak berabad-abad lalu (Hapsari, 2015:99). Pesatnya perkembangan jaman, maka batik pun sekarang mengalami perkembangan yang lebih luas, bentuk maupun fungsinya. Hal ini terjadi karena adanya usaha yang dilakukan manusia dalam menciptakan bentuk-bentuk baru dalam proses perkembangannya.

Batik banyak berkembang seiring dengan perkembangan kebudayaan. Akan tetapi perkembangan yang terus muncul itu tidak menghilangkan ciri khas dari batik yang memiliki nilai tradisional dan memiliki makna dan filosofi mendalam (Hidayat, 2015:2). Setiap karya seni yang dihasilkan mempunyai makna dan filosofi yang luar biasa. Banyak hal yang terungkap dari seni batik, seperti latar belakang budayanya, kepercayaan, adat istiadat, sifat, tata kehidupan, alam lingkungan, cita rasa dan tingkat keterampilan. Dengan batik pula, manusia secara tidak langsung akan belajar untuk sabar, kreatif dan inovatif. Pemaknaan didalam karya ini yang menjadikan batik sebagai wadah dalam menanamkan nilai-nilai karakter. Pendidikan karakter merupakan suatu usaha manusia secara sadar dan terencana untuk mendidik dan memberdayakan potensi peserta didik guna membangun karakter pribadinya sehingga dapat menjadi individu yang bermanfaat bagi diri sendiri dan lingkungannya (Nihayah, 2017: 1653).

Di zaman sekarang, batik tidak hanya dikenakan bangsawan keraton saat kegiatan atau acara yang sifatnya resmi, akan tetapi hampir dari segala lapisan masyarakat memiliki dan pernah mengenakannya dalam berbagai acara. Teknologi yang semakin canggih sangat mendukung perkembangan batik. Hal itu terlihat yang dulunya batik dibuat secara tradisional dengan canting, namun sekarang banyak ditemui produksi batik menggunakan mesin cetak, menggunakan print dalam waktu yang singkat dan dalam jumlah yang sangat banyak. 
Industri batik di Indonedsia telah muncul sejak adanya tradisi membatik Nusantara. Melalui proses perjalanan yang panjang, industri batik Indonesia tetap eksis sampai sekarang. Satu hal yang dapat dilakukan para perajin batik Indonesia dengan meningkatkan kualitas motif batik agar batik yang diproduksi dapat tetap menarik perhatian para konsumen (Briegel, 2018:75). Perajin batik harus menignkatkan kuantitas koleksi motif batik menarik, unik, serta bernilai tinggi agar permintaan konsumen terus meningkat. Untuk itu, inovasi motif batik tersebut, serta strategi pemasaran dinilai penting untuk berkembangnya motif batik Indonesia.

Di Jawa Timur ada beberapa kota penghasil batik yang cukup dikenal baik oleh masyarakat Jawa Timur sendiri maupun masyarakat luar provinsi, seperti batik Madura, batik Jombang, batik Tuban, batik Madiun, batik Ponorogo, serta batik-batik lain di Jawa Timur. Perkembangan batik yang sangat pesat ini membuat para pengrajian batik berfikir untuk menciptakan motif-motif baru yang sangat menarik dan mempunyai nilai jual tinggi. Namun baru-baru ini ada kota penghasil batik yang mulai muncul di Jawa Timur, salah satunya berasal dari Malang dengan batik khas Malangan. Batik Malangan mulai dibuat pada tahun 2008. Namun batik Malangan masih belum menampakkan kecirikhasan Malangan. Pengrajin batik Malangan hanya sebatas membuat tanpa memperhatikan makna dan filosofi. Meskipun batik Malangan belum terkenal seperti batik-batik yang lainnya namun keberadaan batik malangan mulai banyak dilirik oleh pecinta batik dari luarr daerah.

Di Malang, muncul pengrajin yang memproduksi batik khas Malangan dan masih eksis dalam pengembangan batik tulis yaitu Galeri Soendari. Batik hasil pembuatan dari Galeri Soendari ini ialah hasil kerajinan batik asli Indonesia dimana konsepnya ramah lingkungan dan dikerjakan oleh tangan yang terampil. Galeri Soendari ini terletak di Kelurahan Tunggulwulung, Kecamatan Lowokwaru, Kota Malang. Adanya batik Malangan, menambah keanekaragaman batik Jawa Timur. Kelebihan batik khas Malangan yang di buat Galeri Soendari adalah ide gagasan dalam penciptaan motif batik yang unik dan khas Malangan, yaitu diambil berdasarkan ciri khas kota Malang seperti bentuk candi, tugu, budaya dan artefak sejarahnya. Selain itu motif yang dibuat tidak pasaran atau umum, sehingga mampu membuat batik tulis dengan pewarnaan yang unik, exsclusive lain dari yang lain dan sensasional. Kain batik menghasilkan kain yang dengan kualitas tinggi bagi konsumen, tidak mengandung bahan kimia yang aman bagi pemakainya, memiliki rasa dingin dalam pemakaiannya dan ramah lingkungan. Keunikan dan kekhasan motif batik Malangan harus tetap dikembangkan serta diperkenalkan kepada masyarakat supaya lebih digemari dan bisa bersaing dengan batik yang lebih dulu popular.

Berdasarkan motif yang unik dan ide gagasan penciptaan motif batik khas Malangan di Galeri Soendari yang kaya dengan makna-makna simbolis tersebut yang nantinya bisa dikaitkan dengan nilai-nilai utam dari Penguatan Pendidikan Karakter antara lain religius, nasionalis, mandiri, gotong-royong, dan integritas, maka penulis tertarik untuk melakukan penelitian yang berjudul "Visualisasi dan Makna Filosofi Motif Batik Teratai di Galeri Soendari Berbasis Penguatan Pendidikan Karakter".

\section{METODE}

Pendekatan penelitian yang digunakan adalah pendekatan penelitian kualitatif dengan jenis penelitian deskriptif. Tujuannya untuk mengungkap fakta tentang visualisasi motif batik khas Malangan berdasarkan penguatan pendidikan karakter serta fakta tentang makna filosofi motif batik khas Malangan berdasarkan penguatan

Arinta Rezty Wijayaningputri, Belinda Dewi Regina. Visualisasi dan Makna Filosofi Motif Batik Teratai di Galeri Soendari Berbasis 
pendidikan karakter. Hal ini sesuai dengan pendapat Moleong (2007:6) bahwa "penelitian kualitatif adalah penelitian yang bermaksud untuk memahami fenomen secara holistik dan dengan cara deskripsi dalam bentuk kata-kata dan bahasa, pada suatu konteks khusus yang alamiah dengan memanfaatkan berbagai metode alamiah.

Objek dari penelitian ini menganalisis visualisasi dan makna filosofi dari motif batik Malangan, salah satunya adalah Batik Teratai. Motif yang juga dikaitkan dengan visualisasi dan makna filosofi batik khas Malangan berdasarkan penguatan pendidikan karakter. Lokasi penelitian ini terdapat di salah satu Galeri yang terkenal dengan Batik Khas Malangannya, yaitu Galeri Soendari. Instrumen penelitian yang digunakan peneliti sendiri dengan menggunakan alat bantu, untuk mengambil data penelitian ini denggan menggunakan pedoman wawancara pedoman observasi dan studi dokumentasi. untuk menjaring data instrumen yang menyangkut visualisasi batik khas Malangan berdasarkan penguatan pendidikan karakter dan makna filosofi batik khas Malangan berdasarkan penguatan pendidikan karakter. Penelitian ini terletak di Desa Tunggulwulung, Kecamatan Lowokwaru, Kota Malang. Hal ini dikarenakan lokasi menuju Galeri Soendari berdekatan dengan dengan jalan raya, sehingga menjadikan sekolah ini strategis untuk dikunjungi dan mudah dicari.

\section{HASIL DAN PEMBAHASAN}

Visualisasi Motif Batik Teratai di Galeri Soendari Berbasis Penguatan Pendidikan Karakter

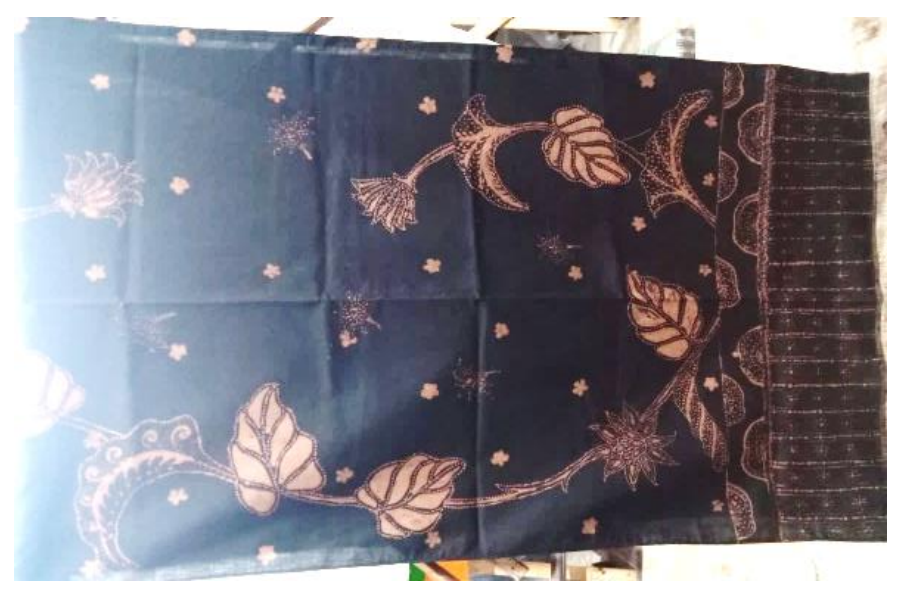

Gambar 1. Motif batik teratai

Bentuk Batik Teratai yang muncul adalah bentuk garis seperti pada motif sulursulur. Bentuk bidang yang muncul pada Batik teratai adalah bentuk pada daun bunga teratai yaitu bentuk oval atau bundar. Bentuk-bentuk itu adalah terdiri bunga Teratai, daun, dan sulur-sulur.selain itu warna yang digunakan pada latar batik teratai adalah dominan warna hitam. Motif bunga teratai yang merupakan salah satu simbol Kota Malang, yang melambangkan keindahan dan kesuburan. Bunga Teratai memiliki bunga yang berkelopak yang indah dan berkarakter elastis yang dapat berayun ketika terhepas oleh angin sehingga mampu memperindah tampilannya menjadi lebih menarik untuk diceritakan dalam bentuk motif batik. Motif batik bunga teratai yang diciptakan dapat menggambarkan karakter teratai yang indah dan menawan saat dipandang mata. Motif batik teratai menggambarkan pikiran manusia untuk belajar mencapai kesempurnaan dalam menjalani kehidupan. Kesempurnaan yang digambarkan dengan keindahan mahkotanya dan usaha mencapai kesempurnaan yang tersirat dalam kehidupan, teratai

Arinta Rezty Wijayaningputri, Belinda Dewi Regina. Visualisasi dan Makna Filosofi Motif Batik Teratai di Galeri Soendari Berbasis Penguatan Pendidikan Karakter 
yang tumbuh di lingkungan berlumpur dan kotor namun tetap dapat berbunga dengan cantik dan menarik. Produk yang dihasilkan dari penerapan motif batik teratai akan diaplikasikan pada dress remaja putri.

Daun dari bunga teratai adalah salah organ yang memiliki peran penting dalam keberlangsungan kehidupan dari tumbuhan Bunga Teratai, karena daun adalah tempat untuk melakukan proses fotosintesis. Bentuk daun dari bunga teratai adalah berbentuk bundar atau oval dan lebar yang dapat terapung di atas air. Selain itu, juga terdapat motif sulur-sulur. Bentuk visual dari sulur-sulur adalah kecil-kecil memanjang. Motif tersebut merupakan simbol bahwa kehidupan itu akan terus berlangsung, tumbuh dan berkembang.

\section{Mendeskripsikan Makna Filosofi Motif Batik Teratai di Galeri Soendari Berbasis Penguatan Pendidikan Karakter}

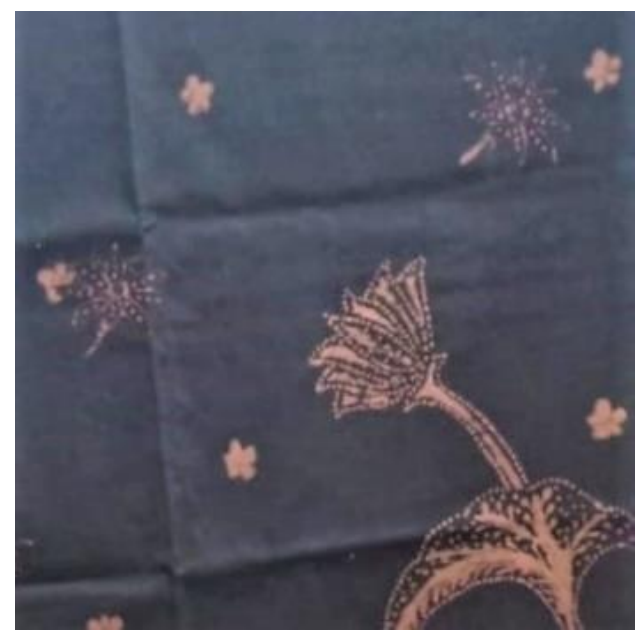

Gambar 2. Motif Bunga Teratai

Di dalam Batik Teratai terdapat tiga motif yang menonjol, antara lain motif bunga teratai, daun bunga teratai, dan sulur-sulur. Bunga Teratai merupakan salah satu simbol Kota Malang, yang melambangkan keindahan juga kesuburan. Pada kisah cerita kuno hindu di era Kerajaan Singosari, bunga teratai merupakan salah satu jenis bunga tempat Dewa Wishnu, sebagai dewa pemelihata alam, bertahta. Makna yang terkandung dari bunga ini yaitu kearifan atau kebijaksanaan yang mengakibatkan kemakmuran bagi masyarakat yang dipimpinnya. Contoh yang paling mudah yaitu kepala keluarga, sehingga sangat pas sekali jika seorang kepala keluarga mengenakan motif batik malang ini dalam bekerja atau mencari nafkah. Diharapkan pemakainya senantiasa subur makmur dan terpelihara jiwa dan raganya.

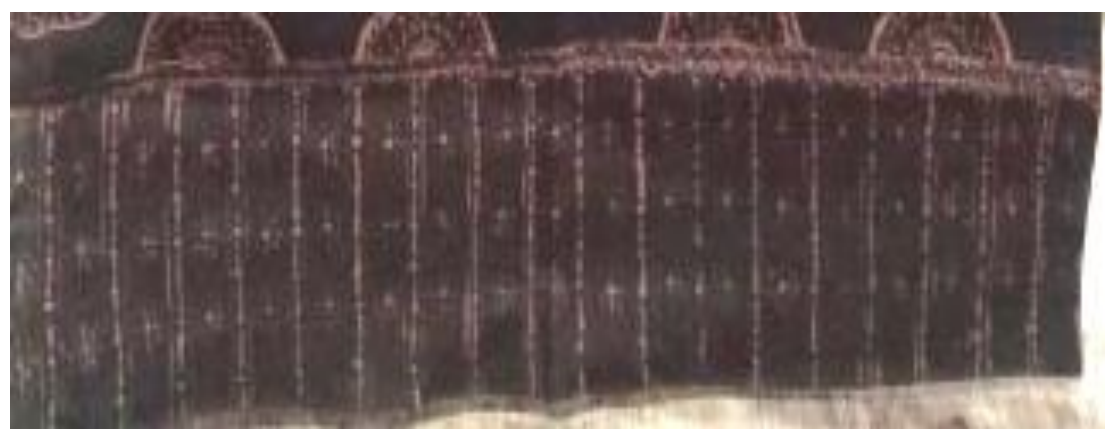

Gambar 3. Sulur-sulur

Arinta Rezty Wijayaningputri, Belinda Dewi Regina. Visualisasi dan Makna Filosofi Motif Batik Teratai di Galeri Soendari Berbasis Penguatan Pendidikan Karakter 
Motif sulur- sulur merupakan simbol bahwa perwujudan suatu kehidupan itu akan terus berlangsung, tumbuh dan berkembang tapi tak abadi dan senantiasa mengingatkan bahwa manusia pasti akan mati. Ada sulur yang terhenti sebagai simbol bahwa kehidupan tidak kekal, namun, sebelum terhenti ada sambungan berikutnya. Yang menunjukkan bahwa manusia itu akan musnah, namun akan selalu berganti generasi yang baru yang akan melanjutkan tujuan kehidupan. Diharapkan pemakainya senantiasa bisa menerima apa yang sudah diberikan guna mengetahui bahwa manusia memiliki batasan-batasan dan bisa introspeksi diri bahwa manusia itu makhluk yang fana.

Pada hakekatnya sulur (tumbuhan) banyak memberi arti dalam kehidupan manusia sebab di alam terdapat keseimbangan antara satu insan dengan makhluk lainnya. Kekaguman manusia terhadap kebesaran alam semesta dengan segala isinya menghasilkan berbagai pandangan. Sebagai bahasa ungkapan simbolik, motif sulur-suluran (tumbuhan) divisualisasikan sedemikian rupa sehingga melahirkan kesan keabadian, kesucian, keagungan, kemakmuran, penangkal bala, dan sebagainya.

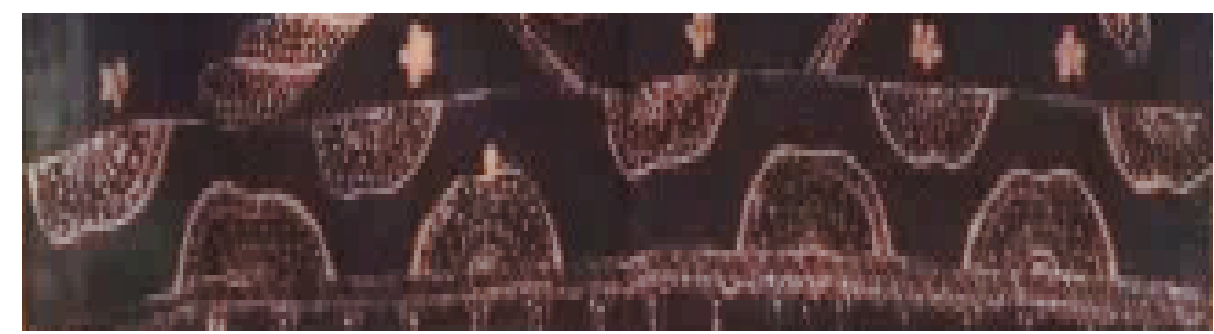

Gambar 4. Motif Daun Bunga Teratai

Di dalam dunia tumbuhan daun merupakan alat pernapasan karena di daun terdapat stomata sebagai tempat proses fotosintesis terjadi. Daun yang lebar pada tumbuhan bunga teratai ini dapat menyatu dengan air, sehingga daun akan melepaskan sejumlah oksigen ke dalam air dan menyerap karbon monoksida dari udara. Hal ini akan menaikkan kadar oksigen dalam air. Daun pada bunga teratai juga mengajarkan kepada kita tentang adaptasi dimana sepertai daun pada bunga tertai yang dapat hidup meskipun di atas air. Daun mampu beradaptasi secara kuat pada lingkungannya. Ini mengajarkan tentang kemandirian. Sehingga jika diartikan secara filosofi, daun mempunyai peran penting untuk melangsungkan kehidupan bagi tumbuhan bunga teratai. Filosofi daun hijau mengajarkan tentang kehidupan kaya yang harus disyukuri dan dijaga.

\section{Analisis Muatan Karakter pada Batik Teratai}

Muatan nilai karakter yang bisa diambil dari Motif Bunga Teratai dapat dilihat dan dianalisis antara lain dari (bentuk/visual) maupun warna yang ada dalam batik teratai. Di dalam Batik Teratai, terdapat warna yang dominan yaitu warna hitam. Secara Filosofi warna hitam mengandung makna positif antara lain mencerminkan keberanian, ketenangan dan dominasi serta keteguhan,kekuatan dan keteguhan hati. Keberanian masuk dalam salah satu dari kelima karakter yaitu integritas. Dimana integritas adalah mutu, sifat, atau keadaan yang menunjukkan kesatuan yang utuh. sehingga memiliki potensi dan kemampuan yang memancarkan kewibawaan, kejujuran. Integritas sepertinya tidak cukup untuk direpresentasikan oleh suatu kejujuran, kecermatan dalam perilaku, keteguhan dalam suatu yang berkomitmen, atau pun keutamaan, kebajikan, serta nilainilai lain yang terkandung seperti: kesederhanaan, kesabaran, visioner, keberanian, kedisiplinan, kerja keras, kerjasama, tanggung jawab, dan sebagainya (Endro, 2017: 150). 
Makna filosofi lainnya dari warna bunga Teratai juga melambangkan spiritual. Seperti contoh Teratai Merah muda dan Teratai putih. Teratai merah muda adalah teratai tertinggi, sering dikaitkan dengan dewa tertinggi, Sang Buddha sendiri. Meskipun sering bingung dengan teratai putih, itu adalah teratai merah muda yang melambangkan Buddha dimana teratai putih digunakan untuk tokoh-tokoh suci yang lebih rendah. Sedangkan Teratai putih melambangkan Bodhi (Sansekerta untuk pencerahan). Murni melambangkan tubuh, pikiran dan jiwa, bersama dengan kesempurnaan spiritual dan perdamaian sifat seseorang. Sebuah bunga teratai umumnya dilengkapi dengan delapan kelopak, yang sesuai dengan Delapan Jalan Hukum Baik. Teratai putih dianggap sebagai teratai dari Buddha (tapi tidak Buddha sendiri) karena disebutkan di atas simbol-simbol yang terkait dengannya. Dimana warna dari bunga teratai ini masuk dalam salah satu dari kelima karakter yaitu religiusitas. Religiusitas seringkali diidentikkan dengan keberagamaan. Religiusitas diartikan sebagai seberapa jauh pengetahuan, seberapa kokoh keyakinan, seberapa pelaksanaan ibadah dan kaidah dan seberapa dalam penghayatan atas agama yang dianutnya. Bagi seorang Muslim, religiusitas dapat diketahui dari seberapa jauh pengetahuan, keyakinan, pelaksanaan dan penghayatan atas agama Islam. Dalam Islam, religiusitas pada garis besarnya tercermin dalam pengamalan akidah, syariah, dan akhlak, atau dengan ungkapan lain: iman, Islam, dan ihsan. Bila semua unsur itu telah dimiliki oleh seseorang, maka dia itulah insan beragama yang sesungguhnya (Effendi, 2008: 12).

Religiusitas sebagai keberagamaan yang berarti meliputi berbagai macam sisi atau dimensi yang bukan hanya terjadi ketika seseorang melakukan perilaku ritual (beribadah), tapi juga ketika melakukan aktivitas lain yang didorong oleh kekuatan supranatural. Sumber jiwa keagamaan itu adalah rasa ketergantungan yang mutlak (sense of depend). Sikap religiusitas dalam suatu masyarakat memiliki pengaruh yang cukup besar terhadap perilaku bersih masyarakat (Yanuarti, 2018 : 38). Beberapa faktor yang mempengaruhi religiusitas, yaitu: a. Pengaruh pendidikan atau pengajaran dan berbagai tekanan sosial (faktor sosial), b. Berbagai pengalaman yang dialami oleh individu dalam membentuk sikap keagamaan.

Lebih mudah lagi jika diambil dari bentuk, misalnya seperti bentuk yang terdapat pada Batik Bunga Teratai, salah satunya adalah bentuk daun pada bunga teratai yang berbentuk lingkaran penuh dan rimpangnya biasa dikonsumsi. Daun berbentuk bundar atau bentuk oval yang lebar yang terpotong pada jari-jari menuju ke tangkai. Permukaan daun tidak mengandung lapisan lilin sehingga air yang jatuh ke permukaan daun tidak membentuk butiran air. Dimana bentuk bundar atau oval bisa menyampaikan banyak makna positif seperti alam, keramahan, kekeluargaan, persahabatan dan cinta. Dimana bentuk bundar atau oval masuk dalam salah satu dari kelima karakter yaitu gotong royong. Gotong royong memiliki nilai yang diwujudkan dalam beberapa bentuk perilaku atau tindakan individu yang dilakukan tanpa mengharap balasan untuk melakukan sesuatu secara bersama" demi kepentingan bersama atau individu. Adapun nilai yang masuk didalam nilai kegotong royongan, diantaranya : Kebersamaan, Persatuan, Rela Berkorban dan Tolong-menolong. Gotong royong merupakan kegiatan yang dikerjakan bersamasama dengan rasa suka rela supaya kegiatan tersebut dapat berjalan dengan lancar, mudah dan ringan. Gotong royong juga selalu diajarkan dalam ajaran islam, dimana Islam selalu mengharapakn semua umat-umatnya saling mencintai, menyayangi dan saling berbagi antar sesama, dimana hal tersebut sangat sejalan dengan prinsip gotong royong. Sikap gotong royong itu seharusnya dimiliki oleh seluruh elemen atau lapisan masyarakat baik di kota juga di pedesaan. Dengan adanya kesadaran tiap elemen atau lapisan masyarakat

Arinta Rezty Wijayaningputri, Belinda Dewi Regina. Visualisasi dan Makna Filosofi Motif Batik Teratai di Galeri Soendari Berbasis Penguatan Pendidikan Karakter 
dalam melakukan setiap kegiatan dengan cara bergotong royong akan merasakan manfaatnya.

Manfaatnya yaitu : agar lingkungan kita dapat dirasakan kebersihan dan keindahannya, terjalinnya rasa solidaritas dalam lingkungan masyarakat, supaya kehidupan dalam bermasyarakat akan lebih baik dengan diadakannya kegiatan gotongroyong, ketentraman dan kedamaian, hal itu akan di rasakan jika antar sesama warga saling peduli dan saling membantu antar sesama. Gotong royong telah tumbuh dan berkembang dalam masyarakat kita sejak lama. Dalam budaya gotong royong melekat nilai-nilai substansi modal sosial. Sebagai modal sosial, gotong royong dapat dijadikan rujukan dan pegangan dalam mencapai kemajuan suatu bangsa (Effendi, 2013: 16).

Batik sendiri sudah menjadi identitas nasional yang dikenal dunia. Oleh karena itu, bangsa Indonesia yang memakai batik adalah bentuk rasa cinta terhadap tanah air. Memakai batik adalah bukti cinta terhadap produksi dalam negeri. Selain itu, dengan memaki batik, juga sekaligus ikut mempromosikan batik kepada dunia. Cinta tanah air merupakan salah satu nilai dari muatan karakter yaitu nasionalisme. Nasionalisme merupakan pemahaman dari masyarakat suatu bangsa yang mempunyai keselarasan kebudayaan, dan wilayah serta kesamaan cita-cita dan tujuan sehingga timbul rasa ingin mempertahankan negaranya, baik dari internal maupun eksternal. Nasionalisme sebagai suatu paham "negara bangsa" yang tumbuh seiring berjalannya waktu dengan berakhirnya suatu zaman kolonialisme serta imperialisme suatu bangsa-bangsa Barat di Dunia Ketiga (Masroer, 2017 : 230).

\section{SIMPULAN}

Berdasarkan hasil penelitian Analisis visualisasi dan Makna Filosofi Batik Teratai Berbasis penguatan Pendidikan Karakter yang telah diuraikan, maka kesimpulan yang diperoleh adalah sebagai berikut : (1) Pola Batik Malangan memiliki ragam hias batik dengan cara pengulangan motif. Outline pada batik Malangan ini cenderung memiliki warna gelap. Perkembangan batik Malangan lebih cenderung mengikuti permintaan pasar, yang mayoritas lebih menyukai warna-warna yang beraneka ragam. Salah satu motif terkenal dan menjadi simbol Batik khas Malangan adalah motif Bunga Teratai. Di dalam Bunga Teratai, terdapat tiga motif yang menonjol antara lain motif bunga teratai itu sendiri, motif daun dari bunga teratai, dan sulur-sulur (2) makna yang terdapat pada semua batik Malangan sangat beragam. Makna filosofi tersebut disesuaikan dengan keyakinan, kebiasaan atau tradisi, serta cara hidup dari masyarakat Malang yang tetap bertahan sampai sekarang untuk dijadikan sebuah makna. Secara umum setiap motif Batik Malangan memiliki makna berbeda-beda, namun ada satu bentuk motif yang selalu tampak hampir di sebagian besar Batik Malangan yaitu bentuk motif bunga teratai. Motif tersebut selalu disertakan dalam penciptaan motif batik Malangan. (3) Analisis Muatan Karakter yang bisa diambil dari Motif Bunga Teratai dapat dilihat dan dianalisis antara lain dari (bentuk/visual) maupun warna yang ada dalam batik teratai. Di dalam Batik Teratai, terdapat warna yang dominan yaitu warna hitam. Secara Filosofi warna hitam mengandung makna positif antara lain mencerminkan keberanian, ketenangan dan dominasi serta keteguhan,kekuatan dan keteguhan hati. Keberanian masuk dalam salah satu dari kelima karakter yaitu integritas. Selain itu, Makna filosofi lainnya dari warna bunga Teratai juga melambangkan spiritual. Seperti contoh Teratai Merah muda dan Teratai putih. Sebuah bunga teratai umumnya dilengkapi dengan delapan kelopak, yang sesuai dengan Delapan Jalan Hukum Baik. Teratai putih dianggap sebagai teratai dari Buddha (tapi tidak Buddha sendiri) karena disebutkan di atas simbol-simbol yang terkait

Arinta Rezty Wijayaningputri, Belinda Dewi Regina. Visualisasi dan Makna Filosofi Motif Batik Teratai di Galeri Soendari Berbasis Penguatan Pendidikan Karakter 
dengannya. Dimana warna dari bunga teratai ini masuk dalam salah satu dari kelima karakter yaitu religiusitas. Bentuk daun pada bunga teratai yang berbentuk bundar atau bentuk oval yang lebar yang terpotong pada jari-jari menuju ke tangkai. Dimana bentuk bundar atau oval bisa menyampaikan banyak makna positif seperti alam, keramahan, kekeluargaan, persahabatan dan cinta. Dimana bentuk bundar atau oval masuk dalam salah satu dari kelima karakter yaitu gotong royong.

\section{REFERENSI}

Asti Musman \& Ambar B.Arini. 2011. Batik: Warisan Adiluhung Nusantara. Yogyakarta: G-media.

A.N. Suyanto. 1986. Sejarah Batik Yogyakarta, Merapi, Yogyakarta, 2002, hlm. 2.; bandingkan dengan Endik S., Seni Membatik, Safir Alam, Jakarta.

Briegel. Guring. 2018. Persepsi Kualitas Batik Tulis. Jurnal Dinamika Kerajinan dan Batik. Vol 35. No 2. Hal 75-84

Effendy, Muhadjir. 2016. Arahan Menteri Pendidikan dan Kebudayaan Muhadjir Effendy dalam Pelatihan Pengembangan Kapasitas untuk Penguatan Pendidikan Karakter di Hotel Santika, Jakarta, 27 Sepember 2016. (transkrip rekaman Kemdikbud).

Endro, Gunardi. 2017. Menyelisik Makna Integritas dan Pertentangannya dengan Korupsi. Jurnal Integritas. Vol. 3 No. 1. Hal. 131-152.

Eska, Edi. 2016. Pengembangan Motif Batik Khas Aceh Gayo. Jurnal Riset Industri. Vol 10. No 1. Hal 12-21.

Hamidin, 2010. Batik Warisan Budaya Asli Indonesia. Yogyakarta: Narasi.

Hasibuan \& Moedjiono. 2006. Proses Belajar Mengajar. Bandung: PT Remaja Rosdakarya.

Hermawati, Adya. Strategi Bersaing: 2017. Batik Malangan Konvensional Melalui Diversifikasi Produk Batik Kombinasi pada UKM Kelurahan Merjosari Malang. Jurnal JIBEKA. Vol 11. No 1. Hal 11-23

Hidayat. 2015. Perancangan Aplikasi Rekomendasi Motif Karawo Berdasarkan Karakter Pengguna Berbasis Budaya Gorontalo. Prosiding. Seminar Nasional Sains dan Teknologi. Hal 1-8.

Koesoema, A. 2010. Pendidikan Karakter. Jakarta: Grasindo

Nihayah, Durrotun. 2017. Implementasi Pendidikan Karakter di SDN 1 Cerme KidulDerme-Gresik. Jurnal JPGSD. Vol 5. No. 03. Hal 1652-1662.

Rosalia, Ravika. 2015. Batik Kabupaten Blitar. Jurnal e Journal. Vol 04. No 01. Hal 4655.

Yanuarti, Eka. 2018. Pengaruh Sikap Religiusitas Terhadap Perilaku Hidup Bersih dan Sehat Masyarakat Kabupaten Rejang Lebong. Jurnal FOKUS Kajian Keislaman dan Kemasyarakatan. Vol 3. No 1. Hal 21-40.

Yudoseputro, Wiyoso. 1986. Pengantar Seni Rupa Islam Indonesia. Bandung: Angkasa. 